Article

\title{
Influence of Sargassum horneri Mitigating Odorous Gas Emissions from Swine Manure Storage Facilities
}

\author{
Lavanya Madhavaraj ${ }^{1}$, Ho-Dong Lim ${ }^{1}$, Kong-Min Kim ${ }^{1}$, Dae-Hyuk Kim ${ }^{2}$ and Gui Hwan Han ${ }^{1, *}$ \\ 1 Center for Industrialization of Agricultural and Livestock Microorganisms (CIALM), 241, \\ Cheomdangwahag-ro, Jeongeup-si 56212, Korea; lavanyamadhavraj@gmail.com (L.M.); \\ eastlake@cialm.or.kr (H.-D.L.); kgm0901@cialm.or.kr (K.-M.K.) \\ 2 Department of Molecular Biology, Institute for Molecular Biology and Genetics, Jeonbuk National University, \\ Jeonju 561-756, Korea; dhkim@jbnu.ac.kr \\ * Correspondence: ghhan@cialm.or.kr; Tel.: +82-63-536-6713; Fax: +82-63-536-6003
}

Received: 4 August 2020; Accepted: 11 September 2020; Published: 15 September 2020

check for updates

\begin{abstract}
Manures from livestock industries and farmyards should be managed for land application. Currently, a deep pit or barn system is adopted by many swine farms for manure management, therefore releasing harmful gases and rising the total global emissions of GHGs. This research focuses on the effectiveness of the brown seaweed Sargassum horneri as a masking agent to mitigate odor-generating gaseous pollutants and reduce the emissions of volatile fatty acids (VFAs) from swine manure storage facilities. Using an optimized procedure, we compared the gaseous emissions from two manure storage barns, one containing swine manure masked with $S$. horneri and the other without masking as a control, over a 30-day period. The results showed that, compared to the control, seaweed masking significantly reduced the sulfide and VFA contents. Furthermore, reductions of $99.48 \%$ in $\mathrm{H}_{2} \mathrm{~S}, 60 \pm 5.21 \%$ in $\mathrm{NH}_{3}$ and $74.28 \pm 2.14 \%$ in gaseous amine emissions were observed within the experimental period. Intriguingly, seaweed masking had beneficial effects, decreasing the total odor content by $97.78 \pm 3.15 \%$ and increasing the nutrient quality of the manure. S. horneri has great potential as a masking agent in swine manure management to control environmental pollution.
\end{abstract}

Keywords: S. horneri; manure additive; mitigation strategy; air quality improvement

\section{Introduction}

The increase in global animal breeding, such as swine and cattle, is the result of human dietary habits and has led to a significant intensification of livestock farming. In 2016, FAOSTAT stated that 1.5 billion swine and 330 million cattle were raised for meat production [1]. Irritating and noxious gas emissions from swine manure storage facilities are one of the major impacts of livestock industries and have a significant influence on air quality, global climate and surrounding neighborhoods. Unfortunately, storage durations of 3 to 10 months are needed for manure decomposition and land application (a nutrient recycling practice) [2,3]. Consequently, livestock industries pollute the environment by emitting gases such as ammonia $\left(\mathrm{NH}_{3}\right)$, amines, hydrogen sulfide $\left(\mathrm{H}_{2} \mathrm{~S}\right)$ and greenhouse gases (GHGs), which have deleterious effects on the environment and organisms [4]. For instance, $\mathrm{NH}_{3}$ is a harmful pollutant because it plays a vital role in the acidification and eutrophication of ecosystems via its oxidation to nitrous oxide [5]. $\mathrm{NH}_{3}$ is also considered an important neurotoxic substance and has negative effects on the health of animals and humans and the environment. At high concentrations, it can cause ulceration to the eyes and severe irritation to the respiratory tract [6]. Atmospheric $\mathrm{H}_{2} \mathrm{~S}$ concentrations greater than $10 \mathrm{ppm}$ are considered stressors for both humans and swine. For example, $\mathrm{H}_{2} \mathrm{~S}$ gas exposure can lead to neurological diseases, respiratory diseases and eye diseases for animals and humans [7]. Additionally, $\mathrm{H}_{2} \mathrm{~S}$ gas, whose density is higher than air, 
can accumulate in the poorly ventilated areas, which intensifies its perilous impact on environment pollution $[7,8]$. Therefore, mitigation strategies that reduce gaseous emissions and control noxious odors are necessary. Several methods have been employed to mitigate the gaseous emissions from waste pits and barns; the incorporation of manure additives is one of the most widely practiced methods by swine producers because of its accessibility and cost-effectiveness $[9,10]$. Various additives that reduce gaseous emissions and odors have been used, such as biochar, sawdust and rice husks. However, biochar is produced via pyrolysis, which takes place at temperatures of $400-800{ }^{\circ} \mathrm{C}$, is relatively expensive and produces a final product with high volatile content and elevated levels of pollutants [11]. Formerly, researchers have utilized biochar for reducing $\mathrm{NH}_{3}$, for instance, Febrisiantosa et al., [12] showed that coadditive (biochar and FGD gypsum) led to a reduction in $\mathrm{NH}_{3}$ volatilization by $26-59 \%$. However, it also increased nitrate accumulation by 6.7-7.9 fold, which is supposed to be harmful to the human health and ecosystem [13]. Several researchers represented that biochar has high absorption capacity and can reduce the greenhouse gases and $\mathrm{NH}_{3}$, although require a high quantity to implement the significant outcome [14]. Some of the strategies used for mitigating odor include organic matter degradation inside manure utilizing biochar, mushroom substrate, rice husks and sawdust as additives and bulking agents during composting process [15-18]. Nevertheless, employing these techniques for odor reduction imposes certain limitations, by the fact that, composting techniques are a slow process, and eventually odor regenerates from the storage manure. Additionally, sawdust and rice husks alone are not effective at reducing gaseous emissions from manure. A summary of the literature describing the performance of these additives in the mitigation of gaseous emissions from livestock industries is shown in Table 1.

Table 1. Summary of the additives utilized to reduce gaseous emissions and compost swine manure in previous studies.

\begin{tabular}{|c|c|c|c|c|c|}
\hline Study & $\begin{array}{l}\text { Manure } \\
\text { Type }\end{array}$ & $\begin{array}{l}\text { Experimental } \\
\text { Scale }\end{array}$ & $\begin{array}{l}\text { Additive } \\
\text { Utilized }\end{array}$ & $\begin{array}{l}\text { Experimental } \\
\text { Duration } \\
\text { (days) }\end{array}$ & $\begin{array}{c}\text { Analysis Performed/Gas } \\
\text { Emissions Reduction Rate (\%) }\end{array}$ \\
\hline Present work & Swine manure & Farm & Seaweed & 30 days & $\begin{array}{c}\mathrm{H}_{2} \mathrm{~S}: 99.48 \%, \mathrm{NH}_{3}: 60 \% \text {, amine: } \\
74.28 \text { and Total odour: } 97.78 \%\end{array}$ \\
\hline [12] & Swine waste & $\begin{array}{l}\text { Small laboratory } \\
\text { composters }\end{array}$ & $\begin{array}{l}\text { Biochar and Flue gas } \\
\text { desulphurization } \\
\text { gypsum }\end{array}$ & 28 days & $\mathrm{NH}_{3}$ volatilization: $26-59 \%$ \\
\hline [19] & Poultry manure & $\begin{array}{l}\text { Small laboratory } \\
\text { composters }\end{array}$ & $\begin{array}{l}\text { Biochar with } \\
\text { wheat straw }\end{array}$ & 42 days & $\mathrm{NH}_{3}$ reduction: $44 \%$ \\
\hline [20] & Poultry manure & $\begin{array}{l}\text { Small laboratory } \\
\text { composters }\end{array}$ & Bamboo biochar & 28 days & $\mathrm{NH}_{3}$ reduction: $47.1 \%$ \\
\hline [22] & Poultry manure & $\begin{array}{c}\text { Small laboratory } \\
\text { composters }\end{array}$ & Biochar & 42 days & $\begin{array}{c}\text { C- }-\mathrm{CO}_{2} \text { emission: } 6.9 \% \text { and total } \\
\text { C- }-\mathrm{CO}_{2} \text { emission: } 7.4 \%\end{array}$ \\
\hline [17] & Poultry manure & $\begin{array}{l}\text { Small laboratory } \\
\text { composters }\end{array}$ & Biochar & 210 days & Organic matter degradation: $70 \%$ \\
\hline [23] & Poultry manure & $\begin{array}{l}\text { Small laboratory } \\
\text { composters }\end{array}$ & $\begin{array}{c}\text { Bamboo charcoal and } \\
\text { bamboo vinegar } \\
\text { with sawdust }\end{array}$ & 15 days & $\begin{array}{l}\mathrm{NH}_{3} \text { reduction: } 21.5-38.5 \% \text { and } \\
\mathrm{CH}_{4} \text { reduction: } 6.1-22.2 \%\end{array}$ \\
\hline [18] & Swine manure & Farm & Sawdust & 63 days & Organic matter degradation $* 3$ \\
\hline
\end{tabular}

Therefore, a new strategy that involves utilizing powder of the brown seaweed Sargassum horneri as a masking agent in industrial applications may provide a cost-effective emissions mitigation strategy because such powder is simpler to produce than biochar. S. horneri is one of the main algal species present along the shores of Jeju Island, Republic of Korea and has become a threat to the local coastal biodiversity $[24,25]$. Besides, this species is considered to have a negative impact on kelp farming, fishery industries and local tourism $[25,26]$. Moreover, Sargassum-based organic fertilizers have improved soil conditions and growth parameters for field crops [27]. Consequently, the addition 
of seaweed to manure as a masking agent has several advantages: (1) an indirect reduction in the amount of seaweed on the coast, thus controlling golden tides [24,25]; (2) the addition of rich nutrients to the manure [28,29]; (3) the odor reduction in swine manure [30]; (4) the development of a sustainable bioadditive for odor mitigation in the livestock industry [30].

In our previous study [30], the effects of S. horneri and a microbial consortium (Bacillus subtilis, Saccharomyces cerevisiae and Thiobacillus sp.) alone and the synergistic effects of this brown seaweed with the microbial consortium on the reduction in swine manure odor were compared in laboratory-scale tests. Therein, we determined seaweed swelling on the surface of the manure due to water absorption achieved in thin masking, contributing $98-100 \%$ control of odors emissions. Against this background, in the present research, for the first time, we evaluated the mitigation of harmful gas emissions such as $\mathrm{H}_{2} \mathrm{~S}, \mathrm{NH}_{3}$, amine, sulfide emissions; the total odor; and the VFA emissions from storage barns containing swine manure from the swine production industry in the Republic of Korea by S. horneri as a masking agent. To the best of our knowledge, this is the first report showing the effects of $S$. horneri as a mitigation strategy for gaseous emissions in field-scale investigations.

\section{Materials and Methods}

\subsection{Materials}

Fresh S. horneri was collected from Wando, Jeollanam-do, Republic of Korea. After collection, the seaweed was washed, dried, crushed into a fine powder and stored at room temperature. Figure 1 depicts the production of the brown seaweed powder.

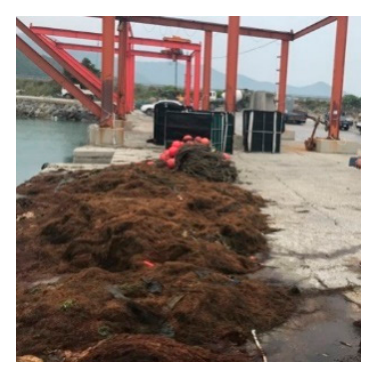

(a)

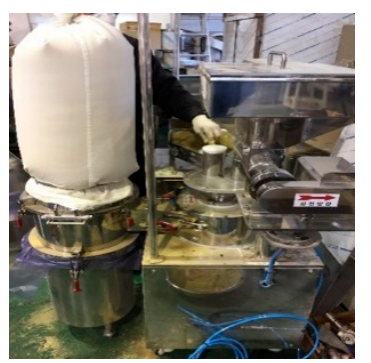

(c)

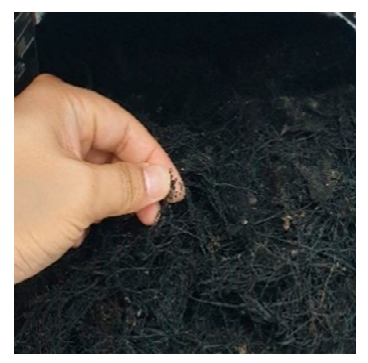

(b)

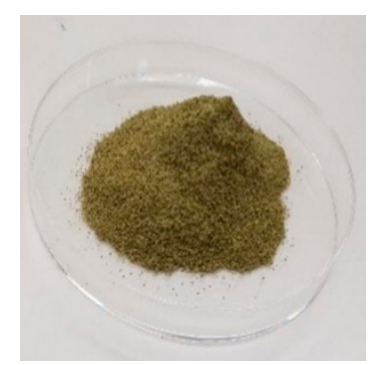

(d)

Figure 1. Pictures of the procedure for seaweed powder production: (a) S. horneri collection from the sea; (b) seaweed drying in the sun for 6 to 7 days; (c) dried seaweed being crushed; (d) seaweed powder.

\subsection{Experimental Description}

The experimental field site was at Yuhan Farm, a commercial pork production farm located in North Jeolla Province, Jeongeup, Republic of Korea ( $35^{\circ} 36^{\prime} 00.1^{\prime \prime} \mathrm{N}$ and $\left.126^{\circ} 56^{\prime} 09.7^{\prime \prime} \mathrm{E}\right)$. The experiment was performed for 30 days beginning on 29 July 2019. Two similar barns $(6.6 \mathrm{~m}$ width and $23.7 \mathrm{~m}$ length) with a distance of $200 \mathrm{~m}$ from each other comprise swine manure (approximately 1-month-old) were used to evaluate the effect of a seaweed masking agent on gaseous emission reduction rates. Throughout the experimental period, manure was maintained at approximately $80 \%$ of the total 
volume of each barn. The control barn contained swine manure without seaweed masking (Barn 1), and the test barn contained swine manure with seaweed masking (Barn 2). S. horneri ( $2 \%$ w/v) seaweed powder was sprayed with a KZ989 (Kazumi, Osaka, Japan) sprayer from the front and side areas of each barn to form a layer at a thickness of $0.25 \mathrm{~cm}$ on the top of the manure [30] (Figure 2). During the experimental period, the average temperature outside and inside each barn (control and test) was recorded every day by a TP-50 thermometer (ThermoPro, Atlanta, Georgia, USA). The gas $\left(\mathrm{NH}_{3}\right.$, amine and $\mathrm{H}_{2} \mathrm{~S}$ ) detections and VFAs content were performed from the front portion of the barns every day at approximately 11 a.m. For a set of 6 consecutive days and the following 3rd day until the end of the experimental period. The total odor and the contents of sulfide and aldehyde gases detections were carried out from the front portion of the barns for the initial and final day of the treatment.

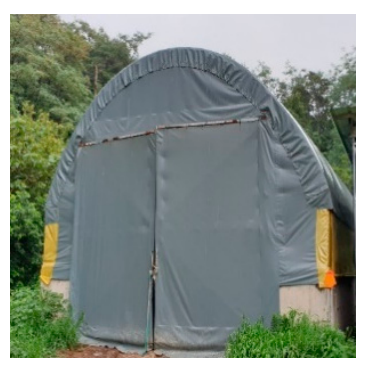

(a)

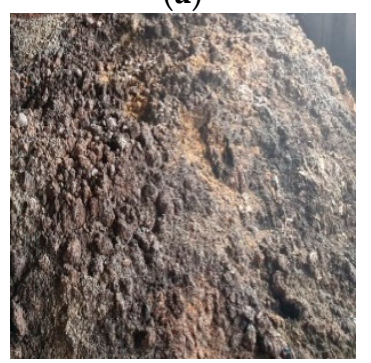

(d)

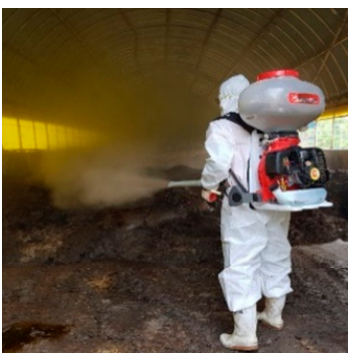

(b)

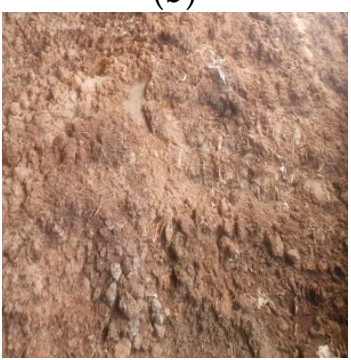

(e)

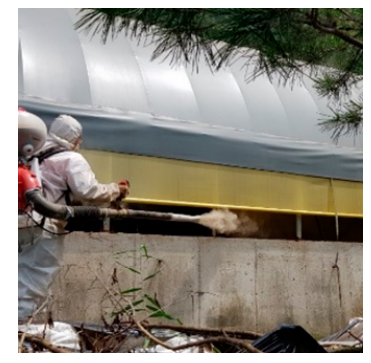

(c)

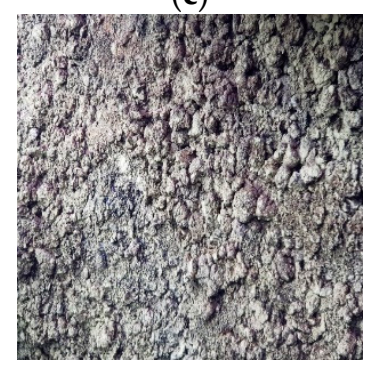

(f)

Figure 2. Method and operation performed in the swine farm industry: (a) swine manure storage barn; (b) spraying a solution of seaweed powder as a masking agent on the front of the manure pile; (c) spraying a solution of seaweed powder as a masking agent on the side of the manure pile; (d) manure before seaweed masking; (e) manure after 10 min of seaweed masking; (f) manure after the 30th day of seaweed masking.

\subsection{Analytical Techniques}

Analysis of gaseous ammonia and amine was performed with a Gastec pump (Gastec Corporation, Ayase-city, Kanagawa, Japan) with detector tubes (no. 3L, no. 3M and no. 180, Gastec, Japan). For analysis of the total odor content; the contents of sulfide gases, such as hydrogen sulfide $\left(\mathrm{H}_{2} \mathrm{~S}\right)$, methyl mercaptan $\left(\mathrm{CH}_{4} \mathrm{~S}\right)$, dimethyl sulfide $\left(\mathrm{C}_{2} \mathrm{H}_{6} \mathrm{~S}\right)$ and dimethyl disulfide $\left(\mathrm{C}_{2} \mathrm{H}_{6} \mathrm{~S}_{2}\right)$; the content of gaseous methyl ethyl ketone $\left(\mathrm{C}_{4} \mathrm{H}_{8} \mathrm{O}\right)$, and the contents of aldehyde gases, such as formaldehyde $\left(\mathrm{CH}_{2} \mathrm{O}\right)$, acetaldehyde $\left(\mathrm{C}_{2} \mathrm{H}_{4} \mathrm{O}\right)$, acrolein $\left(\mathrm{C}_{3} \mathrm{H}_{4} \mathrm{O}\right)$, acetone $\left(\mathrm{C}_{3} \mathrm{H}_{6} \mathrm{O}\right)$, propionaldehyde $\left(\mathrm{C}_{3} \mathrm{H}_{6} \mathrm{O}\right)$, crotonaldehyde $\left(\mathrm{C}_{4} \mathrm{H}_{6} \mathrm{O}\right)$, isobutyraldehyde $\left(\mathrm{C}_{4} \mathrm{H}_{8} \mathrm{O}\right)$, benzaldehyde $\left(\mathrm{C}_{7} \mathrm{H}_{6} \mathrm{O}\right)$, isovaleraldehyde $\left(\mathrm{C}_{5} \mathrm{H}_{10} \mathrm{O}\right)$ and valeraldehyde $\left(\mathrm{C}_{5} \mathrm{H}_{10} \mathrm{O}\right)$, approximately $2 \mathrm{~L}$ gas was collected by a minipump (MP 500NII,SIBATA, Nakane Soka-city, Japan) and stored in polyester aluminum bags (TOP Trading, Bucheon, Korea). Gaseous VFAs were collected using two different types of sorbent tube (ST) gas samplers: (i) a three-bed ST containing Carbopack X, Tenax TA and Carbopack B in a 1:1:1 volume ratio (for aromatics, ketones, esters and alcohols) and (ii) a two-bed ST containing quartz wool and Carbopack C in a 2:8 volume ratio (for VFAs, phenols and indoles). An Agilent J\&W 5975C Series GC/MSD (Santa Clara, CA, USA) with an HP-FFAP capillary column $(30 \mathrm{~m} \times 0.32 \mathrm{~mm} \times 0.25 \mathrm{~mm}$ ) was used to separate the VFAs. The injector temperature was maintained at $250^{\circ} \mathrm{C}$. The GC oven 
temperature was set to $60^{\circ} \mathrm{C}$ for $2.0 \mathrm{~min}$, ramped at $6{ }^{\circ} \mathrm{C} \mathrm{min}-1$ to $145{ }^{\circ} \mathrm{C}$ and then at $20^{\circ} \mathrm{C} \mathrm{min}-1$ to $240^{\circ} \mathrm{C}$, and held for $3.0 \mathrm{~min}$. Helium was utilized as the carrier gas at a flow rate of $1 \mathrm{~mL} \mathrm{~min}{ }^{-1}$. For analysis of the total odor content and the contents of sulfide and aldehyde gases, samples were sent to the Siheung Green Environment Center, Siheung, Republic of Korea. The data were analyzed with IBM SPSS Statistics (Version 23.0. Armonk, NY: IBM Corp.) and determined the independent sample $t$-test and $p$ values. A significant level between control and test was evaluated at a significance level of $p<0.05$. The graphs were created and analyzed with SigmaPlot software (SigmaPlot ${ }^{\circledR}$, version 11).

\section{Results}

\subsection{Effects of Seaweed Masking on Gaseous Ammonia and Amine in Swine Barns}

Figure 3 shows the measured gaseous $\mathrm{NH}_{3}$ and amine concentrations in the control and test barns during the one-month experimental period. The application of the $2 \% \mathrm{w} / \mathrm{v}$ solution of seaweed masking agent resulted in a significant reduction in gaseous $\mathrm{NH}_{3}$ emissions of $67 \pm 2.14 \%(t=8.22 ; p<0.001)$ on day 0 (after spraying seaweed) and of $42 \pm 0.14-62 \pm 2.14 \%(p=0.0341)$ and $60 \pm 2.12 \%$ over the first 6 days and total month of application, respectively (Figure 3a). On the other hand, the control, with no seaweed masking agent applied, showed no significant reduction in gaseous $\mathrm{NH}_{3}$ over the entire test period; in fact, gaseous $\mathrm{NH}_{3}$ emissions increased from $20 \pm 5.21 \mathrm{ppm}$ to $25 \pm 6.41 \mathrm{ppm}$. When the temperature increased outside the barn, the gaseous $\mathrm{NH}_{3}$ concentration increased to approximately $35 \pm 5.21 \mathrm{ppm}$ in the control, creating an excessive odor nuisance in and around the storage barns. In contrast, in the test barn, there was no apparent increase in the gaseous $\mathrm{NH}_{3}$ concentration or odor nuisance when the temperature increased outside the barn (Figure 3a).

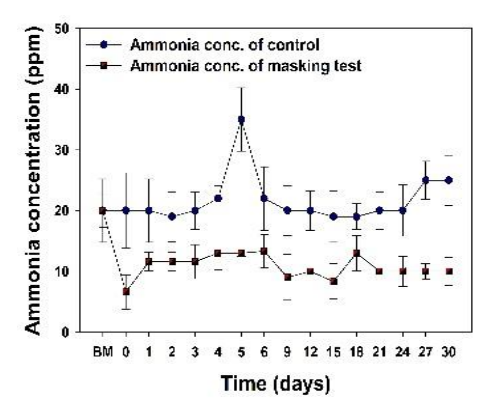

(a)

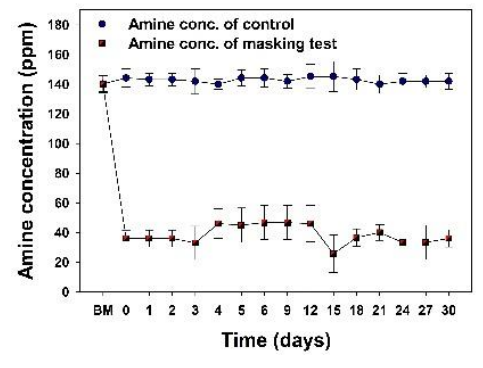

(b)

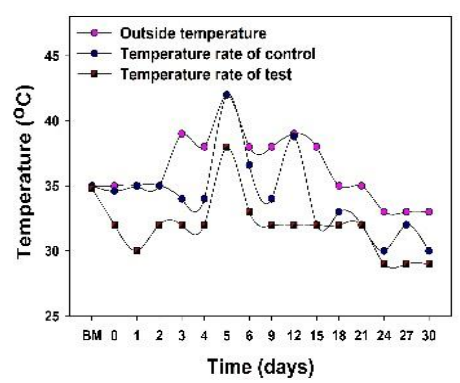

(c)

Figure 3. Effects of seaweed masking on (a) ammonia $(p<0.001)$ and (b) amine $(p<0.001)$ during swine manure storage and (c) variation in the daytime temperature outside the barns and in the control (Barn 1) and test (Barn 2) barns. The results are the mean of three replicates, and error bars indicate the standard deviation. BM-before masking.

Subsequently, Figure $3 \mathrm{~b}$ presents the gaseous amine concentration in the control and test storage barns. In the control, the amine concentration was $140 \pm 2.98 \mathrm{ppm}$ and was constant throughout the experimental period. In the test, the amine concentration was initially similar to that in the control, i.e., $140 \pm 1.42 \mathrm{ppm}$, but after seaweed masking, it decreased to $36 \pm 5.71 \mathrm{ppm}$-a reduction of $74 \pm 28.64 \%$ - and remained at this concentration until day 3 . On day 4 in the test barn, the amine concentration increased to $46 \pm 10.02 \mathrm{ppm}$, where it remained until day 12 . This increase was presumably due to the temperature increase inside and outside the barn during that period (Figure 3c). After day 12 , the amine concentration varied between $25 \pm 12.5$ to $36 \pm 5.77 \mathrm{ppm}$, resulting in an overall reduction of approximately $74.28 \pm 2.41 \%(t=14.95 ; p=0.001)$ compared to that before masking and reflecting good control over the gaseous amine concentration in the test barn.

Finally, Figure $3 \mathrm{c}$ demonstrates the variation in temperature outside the barns and in the control and test barns over the entire experimental period. In storage facilities, the biodegradation of manure could fluctuate with the temperature. As presented in Figure 3c, the temperature in the control barn 
was slightly lower than the outside temperature except on days 5 and 12 when high temperatures were recorded in the barn. Notably, large differences in temperature were observed in the test barn compared with the control barn and outside. The highest temperature recorded in the test barn was $32{ }^{\circ} \mathrm{C}$ for the entire experimental period, except on day 5 , when the outside temperature was very high at approximately $43^{\circ} \mathrm{C}$ and the temperature in the test barn was $37^{\circ} \mathrm{C}$, creating a suitable environment for the microbes in the manure.

\subsection{Effects of Seaweed Masking on the Contents of Sulfide and Aldehydes in Storage Barns}

Gaseous $\mathrm{H}_{2} \mathrm{~S}$ is emitted from the decomposition and metabolization of undigested proteins and sulfur-containing amino acids such as methionine and cysteine in manure [31]. As shown in the profiles in Figure $4 \mathrm{a}$, the concentration of gaseous $\mathrm{H}_{2} \mathrm{~S}$ gradually decreased, with a significant overall reduction of $99.49 \pm 0.53 \%(t=7.43 ; p=0.0241)$ during the experimental period when compared with the control. Furthermore, as illustrated in Figure $4 b$, the total odor content in the test barn was reduced to $144 \pm 6.21 \mathrm{ppb}$, reflecting a reduction of approximately $97.78 \pm 0.49 \%(t=8.06 ; p<0.001)$ over the experimental period. Notably, before the seaweed masking agent was applied, the total odor content was $6463 \pm 22.12 \mathrm{ppb}$, which immediately decreased to $4400 \pm 20.14 \mathrm{ppb}$, reflecting a reduction of $32.23 \%$, after the application.

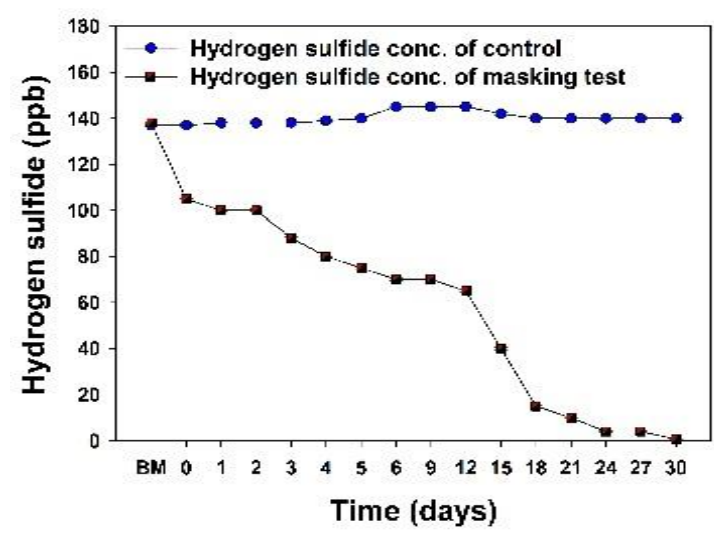

(a)

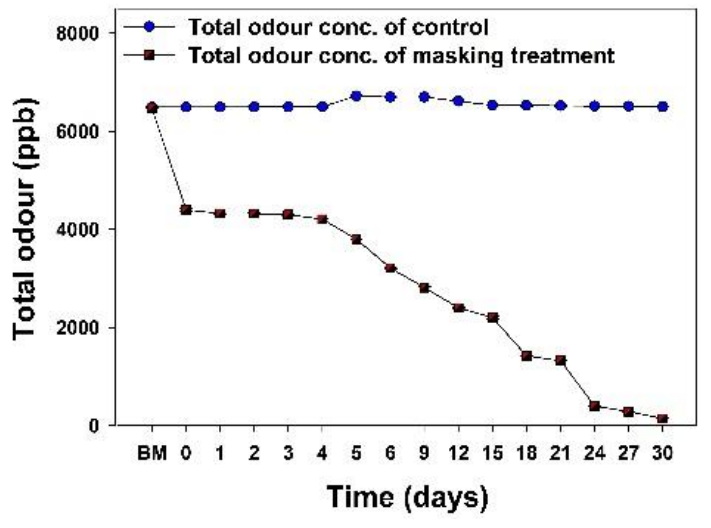

(b)

Figure 4. Effects of seaweed masking on (a) hydrogen sulfide $(p=0.0241)$ and $(\mathbf{b})$ total odor $(p<0.001)$ during swine manure storage. The results are the mean of three replicates, and the error bars indicate the standard deviation. BM - before masking.

In Table 2, the contents of $\mathrm{CH}_{4} \mathrm{~S}, \mathrm{C}_{2} \mathrm{H}_{6} \mathrm{~S}, \mathrm{C}_{2} \mathrm{H}_{6} \mathrm{~S}_{2}$ and $\mathrm{C}_{4} \mathrm{H}_{8} \mathrm{O}$ are shown. No reduction in the initial (day 0) and final (day 30) concentrations of these sulfides were in the control barn. However, in the test barn, a trend level reduction in the sulfide contents of $68.45-99.48 \%$ on day 30 was observed, indicating that seaweed masking can decrease the gaseous emissions from swine manure. 
Table 2. Effects of seaweed masking on the odorous gas emissions in the swine manure storage barns.

\begin{tabular}{ccccc}
\hline Gas & \multicolumn{2}{c}{ Control } & \multicolumn{2}{c}{ Seaweed Masking Treatment } \\
\hline & $\begin{array}{c}\text { Initial (Day 0) } \\
\text { ppb }\end{array}$ & $\begin{array}{c}\text { Final (Day 30) } \\
\text { ppb }\end{array}$ & $\begin{array}{c}\text { Initial (Day 0) } \\
\text { ppb }\end{array}$ & $\begin{array}{c}\text { Final (Day 30) } \\
\text { ppb }\end{array}$ \\
\hline Sulfide Content & & & & \\
Methyl mercaptan & $200 \pm 8.22$ & $210 \pm 3.45$ & $204 \pm 4.11$ & $0.6 \pm 0.32$ \\
Dimethyl sulfide & $41.5 \pm 5.21$ & $48.5 \pm 2.14$ & $42.5 \pm 2.32$ & $6.71 \pm 0.48$ \\
Dimethyl disulfide & $161 \pm 4.21$ & $170 \pm 1.42$ & $166 \pm 1.14$ & $11.1 \pm 0.21$ \\
methyl ethyl ketone & $1.35 \pm 2.12$ & $1.49 \pm 1.65$ & $1.49 \pm 0.88$ & $0.47 \pm 0.42$ \\
Aldehyde Content & & & & \\
Acetaldehyde & $20.21 \pm 0.51$ & $17.43 \pm 0.82$ & $18.2 \pm 0.22$ & $3.43 \pm 2.53$ \\
Acrolein & $0.12 \pm 0.05$ & $0.11 \pm 0.98$ & $0.56 \pm 0.11$ & $0.18 \pm 0.57$ \\
Acetone & $11.0 \pm 0.32$ & $12.0 \pm 1.24$ & $12.0 \pm 0.64$ & $0.29 \pm 0.05$ \\
Propionaldehyde & $0.78 \pm 0.85$ & $0.38 \pm 0.62$ & $0.38 \pm 0.11$ & $4.69 \pm 0.54$ \\
Crotonaldehyde & $0.88 \pm 0.62$ & $0.97 \pm 0.55$ & $0.18 \pm 0.32$ & $0.45 \pm 0.12$ \\
Isobutyraldehyde & $0.83 \pm 0.81$ & $0.88 \pm 0.72$ & $0.23 \pm 0.11$ & $7.43 \pm 0.04$ \\
Benzaldehyde & $0.10 \pm 0.11$ & $0.20 \pm 0.33$ & $0.30 \pm 0.41$ & $0.8 \pm 0.06$ \\
Isovaleraldehyde & $0.42 \pm 0.94$ & $0.49 \pm 0.44$ & $0.39 \pm 0.12$ & $0.36 \pm 0.21$ \\
Valeraldehyde & $0.11 \pm 0.63$ & $0.15 \pm 0.14$ & $0.38 \pm 0.14$ & $0.3 \pm 0.10$ \\
\hline
\end{tabular}

In the present study, masking with S. horneri had a varied effect on the control over gaseous aldehyde emissions, as few of the aldehyde compounds increased in abundance in the test barn over the experimental period (Table 2). However, $\mathrm{C}_{3} \mathrm{H}_{6} \mathrm{O}$, which can trap hydrogen sulfide, decreased by approximately $97.58 \pm 0.54 \%$ in the test barn over the test period. Notably, aldehydes such as $\mathrm{C}_{2} \mathrm{H}_{4} \mathrm{O}$ and $\mathrm{C}_{3} \mathrm{H}_{4} \mathrm{O}$ decreased by $82.63 \pm 2.31 \%$ and $67.85 \pm 1.21 \%$, respectively (trend level difference was observed). In contrast, there was no large difference in the aldehyde content between the initial and final day in the control barn.

\subsection{Reduction in Volatile Fatty Acid Emissions during the Seaweed Masking Treatment}

In Figure 5, acetic acid and propionic acid, which are the major VFAs, composing approximately $60-70 \%$ and $10-20 \%$ of the VFAs emitted from manure [32], were observed. In the test barn, seaweed masking steadily decreased the acetic acid content by approximately $79.61 \pm 2.01 \%(t=4.39 ; p=0.0120)$. In the control, the content of acetic acid $(510 \mathrm{ppb})$ was higher than those of the other acids and did not decrease over the entire experimental period. Similarly, the propionic acid content decreased by $77.56 \pm 1.24 \%(t=10.94 ; p=0.0380)$ after seaweed masking, whereas no change in the propionic acid content was observed in the control.

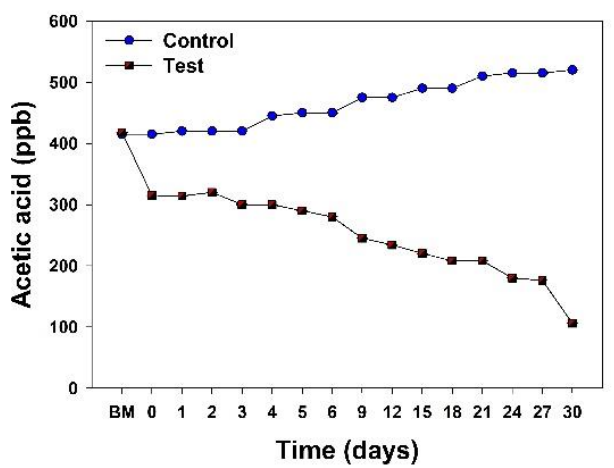

(a)

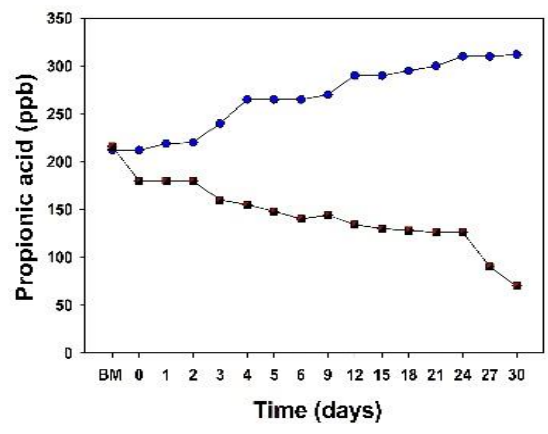

(b)

Figure 5. Effects of seaweed masking on (a) acetic acid $(p=0.0214)$ and $(\mathbf{b})$ propionic acid $(p=0.0380)$ during swine manure storage. The results are the mean of three replicates, and the error bars indicate the standard deviation. BM-before masking. 
Figure $6 \mathrm{a}, \mathrm{b}$ show a rapid decrease in butyric and isobutyric acid by $80 \pm 0.42 \%(t=10.12 ; p=0.0851)$ and $88.88 \pm 1.02 \%(t=7.13 ; p<0.001)$, contributing to the suppression of odor emissions from the swine manure in the test barn. On the other hand, Figure $6 c, d$ demonstrate an initial rapid decrease in the contents of valeric acid $(t=5.82 ; p<0.001)$ and isovaleric acid $(t=4.40 ; p<0.001)$, followed by a gradual decline and ultimate stabilization at zero, resulting in an overall reduction of $100 \%$.

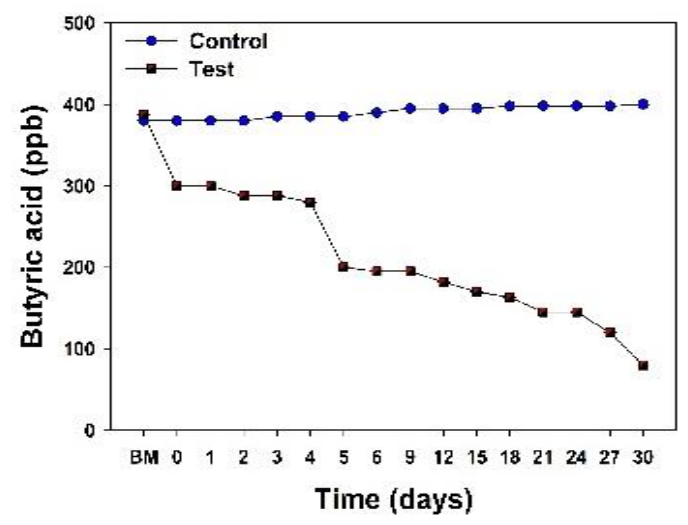

(a)

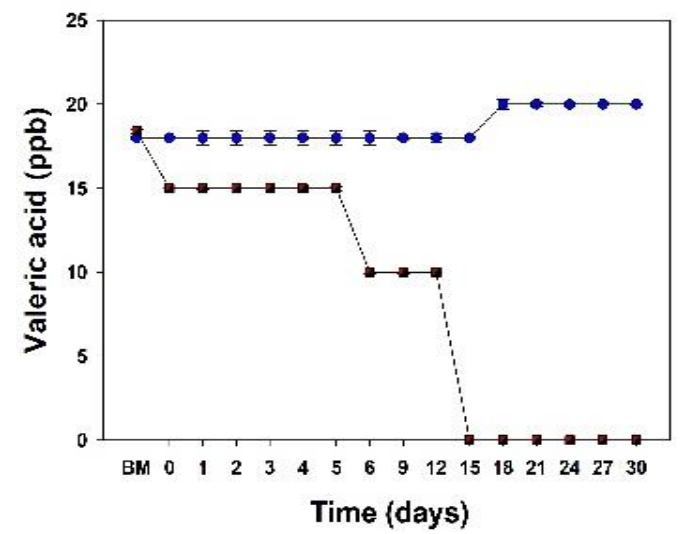

(c)

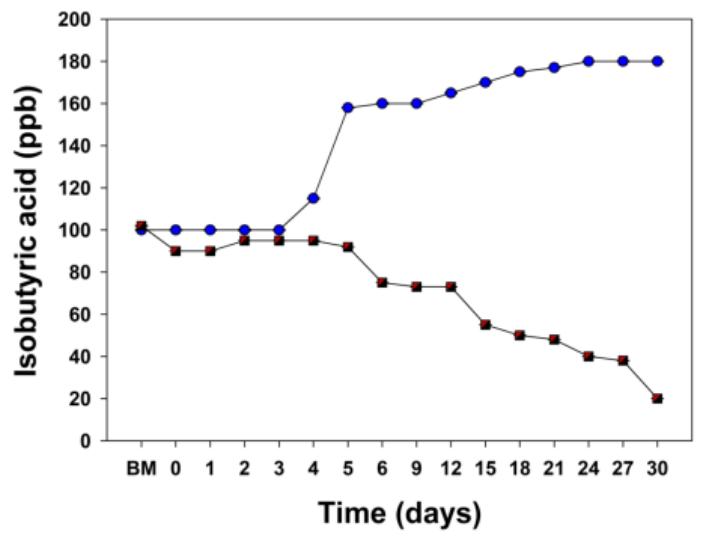

(b)

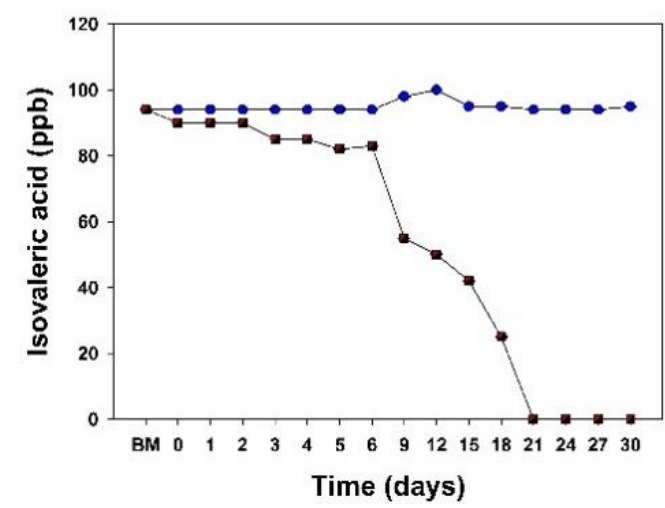

(d)

Figure 6. Effects of seaweed masking on (a) butyric acid $(p=0.0851)$, (b) isobutyric acid $(p<0.001)$, (c) valeric acid $(p<0.001)$ and (d) isovaleric $(p<0.001)$ acid during swine manure storage. The results are the mean of three replicates, and the error bars indicate the standard deviation. BM—before masking.

\section{Discussion}

Odor emissions from swine storage facilities are due to the fermentation of swine manure-which is a mixture of urine and excreta that contains endogenous end products of digestion - by the microbes in the lower gastrointestinal tract. A variety of simple and complex organic compounds can form, which results in gaseous emissions [33]. The most concerning gases in the swine industry are gaseous ammonia, amines and hydrogen sulfide. Excessive levels of ammonia in the swine industry due to the storage of swine manure for long periods can pose a direct hazard to farmers and the animals themselves [34]. Furthermore, a large amount of gaseous ammonia emissions can release heat and cause thermal injury [35]. In addition, monitoring odor emissions are required in environmental management [36]. It is well known that air quality is an essential consideration for animal caretakers working inside facilities and for the animals themselves due to the respiratory issues that poor air quality can cause [37]. The storage of manure for land application generates more odor than other manure management techniques employed in livestock industries [38]. Smith et al. reported that stored solid manure generates high odor emissions for a long period [39], whereas Moseley et al. reported 
that manure injection can reduce odor emissions by $80-85 \%$ compared with emissions from manure land application [40]. In addition, Lau et al. suggested that subsurface deposition (SSD) with the Aerway applicator reduced odor emissions by 8 to $38 \%$ compared with land application emissions [41]. However, Flessa and Beese [42] suggested that manure injection has the potential to enhance gaseous nitrous oxide $\left(\mathrm{N}_{2} \mathrm{O}\right)$ emissions when compared with the surface application. Therefore, the present strategy of surface masking with seaweed may be a viable option for controlling the odor from storage barns via an immediate reduction in the total odor and simultaneously controlling $\mathrm{NH}_{3}$, amine and $\mathrm{H}_{2} \mathrm{~S}$ gaseous emissions. The simple reason of utilizing seaweed as a surface masking agent is that they comprise interesting hydrophilic characteristics, which leads to water absorption, therefore contributing to swelling. This swelling on the surface of the manure results in thin masking, hindering the mass transfer from the inside to the outside surface of the manure [30].

Figure 3 shows that application of the $2 \% \mathrm{w} / \mathrm{v}$ seaweed masking reduced $\mathrm{NH}_{3}$ emissions by $60 \pm 5.21 \%$ and amine emissions by $74 \pm 28.64 \%$, respectively. A similar study by Maurer et al. utilizing nonactivated biochar reported a reduction in gaseous $\mathrm{NH}_{3}$ emissions of 13 to $23 \%$ and suggested that a thin layer of masking agent can be effective at mitigating gaseous emissions [10]. Intriguingly, research has shown that masking agents are most effective at controlling odors by reducing gaseous emissions from stored manure [43]. Additionally, Smith et al. reported that masking agents can be labile to degradation by microorganisms, hence indicating a potential for rapid odor reduction [39]. However, the selection of a masking agent should be a careful consideration, as Maurer et al. suggested that additives that reduce $\mathrm{NH}_{3}$ emissions are capable of increasing GHG emissions [9]. Reports have shown that the amendment of feed with seaweed, especially for cows, can reduce methane emissions by $99 \%$ [44]. It follows that the reduction in and control over the gaseous $\mathrm{NH}_{3}$ and amine concentrations might have been due to the thorough coverage of the swine manure surface by the seaweed, which affected the mass transfer of the gases to the headspace. Thus, the persistent repulsive nuisance odor near the storage barn 1 was suppressed after day 1 until the end of the experimental period. Previous laboratory-scale results from our laboratory demonstrated that $S$. horneri seaweed masking results in good reductions (90-100\%) in gaseous $\mathrm{NH}_{3}$ and amine emissions from swine manure [30]. Consequently, in the current study, the usage of brown seaweed as a masking agent could provide a viable, long-term solution for the reduction in gaseous emissions from storage barns.

Furthermore, Figure $3 \mathrm{c}$ represents the variation in temperature inside the test barn due to amendment of seaweed masking and control barn without seaweed masking. Noticeably, an extensive reduction in temperature was observed in the test barn compared with the control barn and outside. Interestingly, reducing the temperature inside barns is one of the proposed strategies to increase the activity of microbes responsible for reducing the gaseous $\mathrm{NH}_{3}$ concentration and nuisance odor [45]. McCrory et al. suggested that higher temperatures inside storage barns favor the dominant pathway of $\mathrm{NH}_{3}$ production [43], and Bleizgys et al. [46] stated that reducing the temperature inside barns could be an excellent way to reduce $\mathrm{NH}_{3}$ emissions. The above strategies align with the results of the current study, as seaweed masking decreased the barn temperature, consequently reducing gaseous $\mathrm{NH}_{3}$ and amine emissions and eliminating the nuisance odor.

Sulfides, especially hydrogen sulfide $\left(\mathrm{H}_{2} \mathrm{~S}\right)$, are highly toxic not only for humans but also for swine; approximately $10,000 \mathrm{ppb}$ is the recommended exposure limit for $\mathrm{H}_{2} \mathrm{~S}$ gas; 20,000 ppb or more $\mathrm{H}_{2} \mathrm{~S}$ gas concentration can develop loss of appetite, nervousness and possibly pulmonary edema [47]. Figure 4 a represents that the seaweed masking significantly decreased the $\mathrm{H}_{2} \mathrm{~S}$ concentration in the test barn, which indicates the effectiveness of the brown seaweed $S$. horneri as a masking agent. In general, manure in animal facilities consists of a mixture of urine and feces, containing undigested nutrients including protein, phosphorus, nitrogen and potassium [48]. Gaseous $\mathrm{H}_{2} \mathrm{~S}$ is emitted from the decomposition and metabolization of undigested proteins and sulfur-containing amino acids such as methionine and cysteine in manure [31]. Based on the outcome, seaweed addition could stimulate the activity of sulfate-reducing bacteria (SRB) participating in the degradation of organics to effectively reduce gaseous $\mathrm{H}_{2} \mathrm{~S}$ emissions. This is similar to the findings of Aires et al., who reported that seaweed 
enhances the growth of SRB and is involved in sulfate reduction [49]. In this context, Miller et al. suggested that sulfide-utilizing bacteria degrade sulfide compounds present in swine manure, resulting in a reduction in sulfide content in the manure and supporting conditions for the efficient growth and activity of organic matter-digesting bacteria [47].

Table 2 showed the reduction in $\mathrm{CH}_{4} \mathrm{~S}, \mathrm{C}_{2} \mathrm{H}_{6} \mathrm{~S}, \mathrm{C}_{2} \mathrm{H}_{6} \mathrm{~S}_{2}$ and $\mathrm{C}_{4} \mathrm{H}_{8} \mathrm{O}$ contents to about $68.45-99.48 \%$ in the test barns, whereas no significant differences were observed in the control barn, indicating the effects of seaweed masking. Furthermore, dissimilatory sulfate reduction can occur in seaweed-enriched sediments, as revealed by the detection of proteins encoded by upregulated dsr genes [50]. Therefore, the decrease in the sulfide content might be due to the addition of seaweed to the stored swine manure. Furthermore, the aldehyde contents inside swine waste storage facilities are difficult to accurately determine, as aldehydes can react with hydrogen sulfide as trapping agents [51]. Notwithstanding, there was no large difference in the aldehyde content between the initial and final day in the control barn (Table 2). Sánchez-García et al. mentioned that marine seaweed can produce aldehyde compounds depending on the environmental conditions [52], and Sun et al. reported that aldehyde compounds constitute the odor and flavor of seaweed [53]. Therefore, it is reasonable that the addition of S. hornerias as a masking agent resulted in significant increases in the aldehyde emission from the stored swine manure. More research is warranted to determine the mechanisms underlying the effect of $S$. horneri on aldehyde emissions.

The profiles shown in Figs. 5 and 6 demonstrate the significant reduction in the VFA contents after the addition of the seaweed masking agent, which could have been due to the effects of surface masking and the increased activity of VFA-degrading microorganisms inside the manure. Subsequently, the method of manure storage has a significant effect on the magnitude of volatile fatty acid (VFA) emissions in storage facilities. Inefficient degradation of organic waste creates enormous quantities of VFAs [45]. Therefore, it is imperative to increase the activity of organic matter-digesting microorganisms, which enhance the degradation of organic matter usually found in swine manure. In this context, we assessed a strategy to increase the microbiome activities and reduce the emission of VFAs to control the noxious odor emitted from stored swine manure. Figure 5 shows a steady decrease in the acetic acid and propionic acid content compared to the control barn. It should be noted that VFAs are major energy sources for the growth and maintenance of microbiomes: propionic acid is a principal glycogenic precursor, and acetic acid is a primary precursor of fatty acid production [54]. Therefore, the reduction in these acids in manure can ultimately reduce the harmful gas emissions to the environment. In addition, Figure 6 represents the rapid declining of valeric acid and isovaleric acid contents to zero at the end of the experimental period. Furthermore, butyric and isobutyric acid expeditiously decreased, contributing to the removal of noxious odor emissions from the swine manure in the test barn. In conclusion, masking with a $\% \mathrm{w} / \mathrm{v}$ seaweed amendment could increase VFA degradation possibly because of the effect of the seaweed on the environmental conditions, such as a reduction in temperature inside the test barn (Figure 3c), creating favorable conditions for VFA-degrading microbes. Sundberg et al. suggested that sustained low temperatures could stimulate VFA-degrading organisms, thereby reducing the associated odor [55]. Nozhevnikova et al. stated that VFA degradation occurred in low-temperature environments via stimulation of hydrogen and acetate-utilizing methanogens [56]. Additionally, in our previous laboratory-scale study, S. horneri application enhanced the activities of organic matter-degrading bacteria, thereby sustaining a high VFA degradation rate during the treatment of swine manure for odor reduction [26]. Maia et al. reported similar results, in which seaweeds combined with certain substrates decreased VFA production [57]. Overall, S. horneri could effectively suppress the noxious odor in swine manure storage facilities by increasing the activity of organic matter-degrading microorganisms and consequently decreasing the VFA content-especially under high-temperature environmental conditions-and helping to improve the environment for the animal caretakers and animals. Overall, the application of seaweed as a masking agent could instantaneously control odor and gaseous emissions for improved air quality. 


\section{Conclusions}

A new masking strategy to reduce harmful and nuisance gases in swine manure storage barns was developed. Previous applications of S. horneri demonstrated that this species was effective at reducing gaseous emissions from swine manure. However, this is the first assessment of $S$. horneri as a masking agent to reduce the emissions of gaseous $\mathrm{H}_{2} \mathrm{~S}, \mathrm{NH}_{3}$, amines and sulfides and increase the VFA degeneration in a swine manure storage barn, which was tested for one month. Immediate reductions of $23.91 \%$ in $\mathrm{H}_{2} \mathrm{~S}, 67 \%$ in $\mathrm{NH}_{3}$ and $74.28 \%$ in gaseous amines were observed $10 \mathrm{~min}$ after the addition of the seaweed masking agent, and these low levels were maintained or reduced further over the test period. After 30 days, significant reductions in $\mathrm{H}_{2} \mathrm{~S}(99.48 \%), \mathrm{NH}_{3}(60 \%)$ and amine $(74.28 \%)$ emissions were observed, with a concomitant decrease in VFAs of approximately $77-100 \%$. Interestingly, a reduction $(97.78 \%)$ in the total odor was observed in and around the test barn. More work is warranted to compare and evaluate the seaweed masking of different types of manure and analyze the comprehensive control of odors, $\mathrm{H}_{2} \mathrm{~S}, \mathrm{NH}_{3}$ and greenhouse gas (GHG) emissions from the livestock industries. In conclusion, masking manure with $S$. horneri could be an effective approach to rapidly control gaseous emissions and reduce odors from swine manure storage facilities.

Author Contributions: G.H.H. conceived the study; L.M. designed and performed the experiments; H.-D.L. and K.-M.K. analyzed the data; D.-H.K. contributed material/analysis tools, and L.M. wrote the paper. All authors have read and agreed to the published version of the manuscript.

Funding: This work was supported by the Korea Institute of Planning and Evaluation for Technology in Food, Agriculture and Forestry (IPET) through the Agriculture and Livestock Machinery/Equipment Industry Technology Development Program (No. 318012-4) and funded by the Ministry of Agriculture, Food and Rural Affairs (MAFRA) and the Next-Generation BioGreen 21 Program (Project No. PJ013307), Rural Development Administration, Republic of Korea.

Acknowledgments: The authors would like to thank the Center for Industrialization of Agricultural and Livestock Microorganisms (CIALM), the IPET project (No. 318012-4) and the MAFRA project (No. PJ013307).

Conflicts of Interest: The authors declare no conflict of interest.

\section{References}

1. FAOSTAT. FAOSTAT Emissions Database. Available online: http://www.fao.org/faostat/en/\#home (accessed on 21 February 2014).

2. Dennehy, C.; Lawlor, P.G.; Jiang, Y.; Gardiner, G.E.; Xie, S.; Nghiem, L.D.; Zhan, X. Greenhouse Gas Emissions from Different Pig Manure Management Techniques: A Critical Analysis. Front. Environ. Sci. Eng. 2017, 11, 11. [CrossRef]

3. Schiffman, S.S. Livestock Odors: Implications for Human Health and Well-Being. J. Anim. Sci. 1998, 76, 1343-1355. [CrossRef] [PubMed]

4. Kim, K.Y.; Jong Ko, H.; Tae Kim, H.; Shin Kim, Y.; Man Roh, Y.; Min Lee, C.; Nyon Kim, C. Quantification of Ammonia and Hydrogen Sulfide Emitted from Pig Buildings in Korea. J. Environ. Manag. 2008, 88, 195-202. [CrossRef] [PubMed]

5. Schauberger, G.; Piringer, M.; Mikovits, C.; Zollitsch, W.; Hörtenhuber, S.J.; Baumgartner, J.; Niebuhr, K.; Anders, I.; Andre, K.; Hennig-Pauka, I.; et al. Impact of Global Warming on the Odour and Ammonia Emissions of Livestock Buildings Used for Fattening Pigs. Biosyst. Eng. 2018, 175, 106-114. [CrossRef]

6. Dasarathy, S.; Mookerjee, R.P.; Rackayova, V.; Thrane, V.R.; Vairappan, B.; Ott, P.; Rose, C.F. Ammonia Toxicity: From Head to Toe? Metab. Brain Dis. 2017, 32, 529-538. [CrossRef]

7. Lewis, R.J.; Copley, G.B. Chronic Low-Level Hydrogen Sulfide Exposure and Potential Efects on Human Health: A Review of the Epidemiological Evidence. Crit. Rev. Toxicol. 2014, 45, 93-123. [CrossRef] [PubMed]

8. Verma, S.; Boucher, O.; Reddy, M.S.; Upadhyaya, H.C.; Le Van, P.; Binkowski, F.S.; Sharma, O.P. Modeling and Analysis of Aerosol Processes in an Interactive Chemistry General Circulation Model. J. Geophys. Res. 2007, 112, D03207. [CrossRef]

9. Maurer, D.L.; Koziel, J.A.; Harmon, J.D.; Hoff, S.J.; Rieck-Hinz, A.M.; Andersen, D.S. Summary of Performance Data for Technologies to Control Gaseous, Odor, and Particulate Emissions from Livestock Operations: Air Management Practices Assessment Tool (AMPAT). Data Brief. 2016, 7, 1413-1429. [CrossRef] 
10. Maurer, D.; Koziel, J.; Kalus, K.; Andersen, D.; Opalinski, S. Pilot-Scale Testing of Non-Activated Biochar for Swine Manure Treatment and Mitigation of Ammonia, Hydrogen Sulfide, Odorous Volatile Organic Compounds (VOCs), and Greenhouse Gas Emissions. Sustainability 2017, 9, 929. [CrossRef]

11. Gelardi, D.L.; Li, C.; Parikh, S.J. An Emerging Environmental Concern: Biochar-Induced Dust Emissions and Their Potentially Toxic Properties. Sci. Total Environ. 2019, 678, 813-820. [CrossRef]

12. Febrisiantosa, A.; Ravindran, B.; Choi, H.L. The Effect of Co-Additives (Biochar and FGD Gypsum) on Ammonia Volatilization During the Composting of Livestock Waste. Sustainability 2018, 10, 795. [CrossRef]

13. Renseigné, N.; Umar, S.; Iqbal, M. Nitrate Accumulation in Plants, Factors Affecting the Process, and Human Health Implications. A review. Agron. Sustain. Dev. 2007, 27, 45-57.

14. Ravindran, B.; Nguyen, D.D.; Chaudhary, D.K.; Chang, S.W.; Kim, J.L.S.R.; Shin, J.; Jeon, B.H.; Chung, S.L.J. Influence of Biochar on Physico-Chemical and Microbial Community During Swine Manure Composting Process. J. Environ. Manag. 2019, 232, 592-599. [CrossRef] [PubMed]

15. Hageman, N.; Subdiaga, E.; Orsetti, S.; Maria, J. Effect of Biochar Amendment on Compost Organic Matter Composition Following Aerobic Composting of Manure. Sci. Total Environ. 2018, 613-614, 20-29. [CrossRef]

16. Meng, X.; Liu, B.; Xi, C.; Luo, X.; Yuan, X.; Wang, X.; Zhu, W.; Wang, H.; Cui, Z. Effect of Pig Manure on the Chemical Composition and Microbial Diversity During Cocomposting with Spent Mushroom Substrate and Rice Husks. Bioresour. Technol. 2018, 251, 22-30. [CrossRef]

17. Dias, B.O.; Silva, C.A.; Higashikawa, F.S.; Roig, A.; Sanchez-Mondereo, M. Use of Biochar as Bulking Agent for the Composting of Poultry: Effect on Organic Matter Degradation and Humification. Biores. Technol. 2010, 101, 1239-1246. [CrossRef]

18. Huang, G.F.; Wu, Q.T.; Wong, J.W.C.; Nagar, B.B. Transformation of Organic Matter During Co-Composting of Pig Manure with Sawdust. Bioresour. Technol. 2006, 97, 1834-1842. [CrossRef]

19. Janczak, D.; Malińska, K.; Czekała, W.; Cáceres, R.; Lewicki, A.; Dach, J. Biochar to Reduce Ammonia Emissions in Gaseous and Liquid Phase During Composting of Poultry Manure with Wheat Straw. Waste Manag. 2017, 66, 36-45. [CrossRef]

20. Liu, N.; Zhou, J.; Han, L.; Ma, S.; Sun, X.; Huang, G. Role and Multi-Scale Characterization of Bamboo Biochar During Poultry Manure Aerobic Composting. Bioresour. Technol. 2017, 241, 190-199. [CrossRef]

21. Chowdhury, M.A.; de Neergaard, A.; Jensen, L.S. Potential of Aeration Flow Rate and Bio-Char Addition to Reduce Greenhouse Gas and Ammonia Emissions During Manure Composting. Chemosphere 2014, 97, 16-25. [CrossRef]

22. Czekała, W.; Malińska, K.; Cáceres, R.; Janczak, D.; Dach, J.; Lewicki, A. Cocomposting of Poultry Manure Mixtures Amended with Biochar - the Effect of Biochar on Temperature and C-CO2 Emission. Bioresour. Technol. 2016, 200, 921-927. [CrossRef] [PubMed]

23. Chen, Y.X.; Huang, X.D.; Han, Z.Y.; Huang, X.; Hu, B.; Shi, D.Z.; Wu, W.X. Effects of Bamboo Charcoal and Bamboo Vinegar on Nitrogen Conservation and Heavy Metals Immobility During Pig Manure Composting. Chemosphere 2010, 78, 1177-1181. [CrossRef] [PubMed]

24. Kim, H.S.; Sanjeewa, K.K.A.; Fernando, I.P.S.; Ryu, B.; Yang, H.-W.; Ahn, G.; Kang, M.C.; Heo, S.J.; Je, J.G.; Jeon, Y.J. A Comparative Study of Sargassum horneri Korea and China Strains Collected Along the Coast of Jeju Island South Korea: Its Components and Bioactive Properties. Algae 2018, 33, 341-349. [CrossRef]

25. Sanjeewa, K.K.; Fernando, I.P.; Kim, E.A.; Ahn, G.; Jee, Y.; Jeon, Y.J. Anti-Inflammatory Activity of a Sulfated Polysaccharide Isolated from an Enzymatic Digest of Brown Seaweed Sargassum horneri in RAW 264.7 Cells. Nutr. Res. Pract. 2017, 11, 3-10. [CrossRef]

26. Grebe, G.S.; Byron, C.J.; Gelais, A.S.; Kotowicz, D.M.; Olson, T.K. An Ecosystem Approach to Kelp Aquaculture in the Americas and Europe. Aquac. Rep. 2019, 15, 100-215. [CrossRef]

27. Badar, R.; Khan, M.; Batool, B.; Shabbir, S. Effects of Organic Amendments in Comparison with Chemical Fertilizer on Cowpea Growth. Int. J. Appl. Res. 2015, 1, 66-71.

28. Mohanty, D.; Adhikary, S.P.; Chattopadhyay, G.N. Seaweed Liquid Fertilizer (SLF) and its Role in Agriculture Productivity. Ecoscan 2013, 3, 147-155.

29. Salma, L.; Aymen, E.M.; Maher, S.; Hassen, A.; Cherif, H.H.C.; Mimoun, E. Effect of Seaweed Extract of Sargassum vulgare on Germination Behavior of Two Bean Cultivars (Phaseolus vulgaris L) under Salt Stress. IOSR J. Agric. Veterinary Sci. 2014, 7, 116-120. [CrossRef] 
30. Lavanya, M.; Lim, H.D.; Kim, K.-M.; Kim, D.H.; Ravindran, B.; Han, G.H. A Novel Strategy for Gas Mitigation During Swine Manure Odour Treatment Using Seaweed and a Microbial Consortium. Front. Environ. Sci. Eng. 2020, 14, 53. [CrossRef]

31. Aldin, S.; Tu, F.; Nakhla, G.; Ray, M.B. Simulating the Degradation of Odour Precursor in Primary and Waste-Activated Sludge During Anaerobic Digestion. Appl. Biochem. Biotechnol. 2011, 164, 1292-1304. [CrossRef]

32. Conn, K.L.; Tenuta, M.; Lazarovits, G. Liquid Swine Manure can Kill verticillium dahliae microsclerotia in Soil by Volatile Fatty Acid, Nitrous Acid, and Ammonia Toxicity. Phytopathology 2005, 95, 28-35. [CrossRef] [PubMed]

33. Cho, S.; Hwang, O.; Park, S. Effect of Dietary Protein Levels on Composition of Odorous Compounds and Bacterial Ecology in Pig Manure. Asian-Australas. J. Anim. Sci. 2015, 28, 1362-1370. [CrossRef]

34. Ni, J.Q.; Heber, A.; Lim, T. Ammonia and hydrogen sulfide in swine production. In Air Quality and Livestock Production; Banhazi, T., Aland, A., Hartung, J., Eds.; CRC Press: London, UK, 2018; pp. $29-47$.

35. O'Kane, G.J. Inhalation of Ammonia Vapour. A Report on the Management of Eight Patients During the Acute Stages. Anaesthesia 1983, 38, 1208-1213. [CrossRef]

36. Loftus, C.; Yost, M.; Sampson, P.; Torres, E.; Arias, G.; Vasquez, V.B.; Hartin, K.; Armstrong, J.; Tchong-French, M.; Vedal, S.; et al. Ambient Ammonia Exposures in an Agricultural Community and Pediatric Asthma Morbidity. Epidemiology 2015, 26, 794-801. [CrossRef] [PubMed]

37. Guo, H.; Feddes, J.; Lague, C. Odour monitoring by trained resident-observers in the neighboring area of swine production operations. In Paper-American Society of Agricultural Engineers; ASAE: St. Joseph, MI, USA, 2005; pp. 374-382.

38. Misselbrook, T.H.; Hobbs, P.J.; Persaud, K.C. Use of an Electronic Nose to Measure Odour Concentration Following Application of Cattle Slurry to Grassland. J. Agric. Eng. Res. 1997, 66, 213-220. [CrossRef]

39. Smith, E.; Gordon, R.; Campbell, A.; Bourque, C. An Assessment of Odour Emissions from Land Applied Swine Manure. Can. Biosyst. Eng. 2007, 49, 6.

40. Moseley, P.J.; Misselbrook, T.H.; Pain, B.F.; Earl, R.; Godwin, R.J. The Effect of Injector Tine Design on Odour and Ammonia Emissions Following Injection of Biosolids into Arable Cropping. J. Agric. Eng. Res. 1998, 71, 385-394. [CrossRef]

41. Lau, A.; Bittman, S.; Lemus, G. Odor Measurements for Manure Spreading Using a Subsurface Deposition Applicator. J. Environ. Sci. Health B. 2003, 38, 233-240. [CrossRef]

42. Flessa, H.; Beese, F. Laboratory Estimates of Trace Gas Emissions Following Surface Application and Injection of Cattle Slurry. J. Environ. Qual. 2000, 29, 262-268. [CrossRef]

43. McCrory, D.F.; Hobbs, P.J. Additives to Reduce Ammonia and Odor Emissions from Livestock Wastes: A review. J. Environ. Qual. 2001, 30, 345-355. [CrossRef]

44. Yale Environment 360. Available online: https://e360.yale.edu/features/how-eating-seaweed-can-help-cowsto-belch-less-methane (accessed on 2 July 2018).

45. Zhu, J. A Review of Microbiology in Swine Manure Odor Control. Agric. Ecosyst. Environ. 2000, 78, 93-106. [CrossRef]

46. Bleizgys, R.; Bagdoniene, I.; Balezentiene, L. Reduction of the Livestock Ammonia Emission Under the Changing Temperature During the Initial Manure Nitrogen Biomineralization. Sci. World J. 2013. [CrossRef] [PubMed]

47. Treatment of Animal Waste. Available online: https://patents.google.com/patent/US6410305B1/en?oq=US+ $6 \% 2 c 410 \% 2 c 305+$ (accessed on 1 August 2020).

48. Kelleher, B.; Leahy, J.J.; Henihan, A.M.; O’Dwyer, T.F.; Sutton, D.; Leahy, M.J. Advances In Poultry Litter Disposal Technology-A Review. Bioresour. Technol. 2002, 83, 27-36. [CrossRef]

49. Aires, T.; Muyzer, G.; Serrao, E.A.; Engelen, A.H. Seaweed Loads Cause Stronger Bacterial Community Shifts in Coastal Lagoon Sediments than Nutrient Loads. Front. Microbiol. 2019, 9, 3283. [CrossRef]

50. Morrison, J.M.; Murphy, C.L.; Baker, K.; Zamor, R.M.; Nikolai, S.J.; Wilder, S.; Elshahed, M.S.; Youssef, N.H. Microbial Communities Mediating Algal Detritus Turnover Under Anaerobic Conditions. PeerJ 2017, 5, e2803. [CrossRef]

51. Aqueous Aldehyde Solutions for Trapping, Hydrogen Sulfide in Natural Gas and Crude Oil Producing Plants. Available online: https://patents.google.com/patent/US5225103A/en?oq=5\%2c225\%2c103 (accessed on 1 August 2020). 
52. Sanchez-Garcia, F.; Mirzayeva, A.; Roldan, A.; Castro, R.; Palacios, V.; Garcia-Barroso, C.; Duran-Guerrero, E. Evolution of Volatile Compounds and Sensory Characteristics of Edible Green Seaweed (Ulva rigida) during Storage at Different Temperatures. J. Sci. Food Agric. 2019, 99, 5475-5482. [CrossRef]

53. Sun, S.M.; Chung, G.H.; Shin, T.S. Volatile Compounds of the Green Alga, Capsosiphon Fulvescens. J. Appl. Phycol. 2011, 24, 1003-1013. [CrossRef]

54. Bergman, E.N. Energy Contributions of Volatile Fatty Acids from the Gastrointestinal Tract in Various Species. Physiol. Rev. 1990, 70, 567-590. [CrossRef]

55. Sundberg, C.; Smars, S.; Jonsson, H. Low pH as an Inhibiting Factor in the Transition from Mesophilic to Thermophilic Phase in Composting. Bioresour. Technol. 2004, 95, 145-150. [CrossRef]

56. Nozhevnikova, A.N.; Rebac, S.; Kotsyubenko, O.R.; Parshina, S.N.; Holliger, C.; Lettinga, G. Anaerobic Production and Degradation of Volatile Fatty Acids in Low Temperature Environments. Water Sci. Technol. 2000, 41, 39-46. [CrossRef]

57. Maia, M.R.G.; Fonseca, A.J.M.; Oliveira, H.M.; Mendonça, C.; Cabrita, A.R.J. The Potential Role of Seaweeds in the Natural Manipulation of Rumen Fermentation and Methane Production. Sci. Rep. 2016, 6, 32321. [CrossRef] [PubMed]

(C) 2020 by the authors. Licensee MDPI, Basel, Switzerland. This article is an open access article distributed under the terms and conditions of the Creative Commons Attribution (CC BY) license (http://creativecommons.org/licenses/by/4.0/). 